Article

\title{
Estimating the Impact of Inflow on the Chemistry of Two Different Caldera Type Lakes Located on the Bali Island (Indonesia)
}

\author{
Żaneta Polkowska ${ }^{1, *}$, Lidia Wolska ${ }^{1,2}$, Leszek Lęczyński ${ }^{3}$, Marek Ruman ${ }^{4,5}$, Sara Lehmann ${ }^{1}$, \\ Katarzyna Kozak ${ }^{1}$, Magdalena Matysik ${ }^{4,5}$ and Damian Absalon ${ }^{4,5}$
}

1 Department of Analytical Chemistry, Chemical Faculty, Gdansk University of Technology (GUT), 11/12 G. Narutowicza Str., Gdańsk 80-233, Poland; E-Mails: lidia.wolska@pg.gda.pl (L.W.); sara.lehmann8@gmail.com (S.L.); katarzynakozak.gda@o2.pl (K.K.)

2 Department of Environmental Toxicology, Faculty of Health Sciences with Subfaculty of Nursing, Medical University of Gdansk, Powstania Styczniowego Str. 9b, Gdynia 81-519, Poland

3 Laboratory of Applied Geology, Institute of Oceanography, University of Gdansk, Piłsudskiego Str 46, Gdynia 81-378, Poland; E-Mail: ocell@ug.edu.pl

4 Faculty of Earth Sciences, University of Silesia, 60 Będzińska St., Sosnowiec 41-200, Poland; E-Mails: marek.ruman@us.edu.pl (M.R.); magdalena.matysik@us.edu.pl (M.M.); damian.absalon@us.edu.pl (D.A.)

5 Centre for Polar Studies KNOW (Leading National Research Centre), 60 Bedzinska St., Sosnowiec 41-200, Poland

* Author to whom correspondence should be addressed; E-Mail: zanpolko@pg.gda.pl; Tel.: +48-58-347-2110; Fax: +48-58-347-2694.

Academic Editors: Say-Leong Ong and Jiangyong $\mathrm{Hu}$

Received: 9 October 2014 / Accepted: 7 April 2015 / Published: 21 April 2015

\begin{abstract}
This paper is a preliminary attempt to assess the composition of pollutants in two different caldera lakes situated in the Indonesian Archipelago: Batur and Bratan. Both lakes are characterized by largely different physico-chemical regimes; Batur Lake is located in an area that is currently volcanically active, unlike Bratan Lake. The latter is much smaller and shallower than Batur Lake. The concentration of pollutants in the Indonesian equatorial lakes is largely unknown, and the impact of both biological and geothermal processes on their distribution requires attention. This study shows that the concentrations of cations $\left(\mathrm{Na}^{+}, \mathrm{K}^{+}, \mathrm{Mg}^{2+}, \mathrm{Ca}^{2+}\right)$, anions $\left(\mathrm{SO}_{4}{ }^{2-}, \mathrm{F}^{-}, \mathrm{Cl}^{-}, \mathrm{Br}^{-}\right)$and trace elements (Li, B, Al, V, Cr, Mn, Co, Ni, Cu, Zn, As, Se, Rb, Sr, Mo, Cd, Sn, Cs, Ba, Pb, U,
\end{abstract}


$\mathrm{Be}, \mathrm{Ag}, \mathrm{Sb}, \mathrm{Tl}, \mathrm{Bi})$ differ greatly between both lakes. Most chemical parameters determined in volcanically influenced Batur Lake were tens to hundreds times higher than in Bratan Lake, and in the case of trace metals, the ratios of the two lakes' concentrations reached several hundreds. This study also compared the composition and concentration levels of organic compounds in both lakes, such as fatty acids, halocarbons and esters. On the other hand, the content of organic chemicals in the lakes also results from biological activity by phytoplankton, zooplankton and bacteria.

Keywords: caldera type lake; water pollution; ions; trace elements; total organic carbon (TOC); fatty acids

\section{Introduction}

Volcanic lakes can range in salinity from very low to hyper-acidic-brines. Variations in lake-water chemistry are related to variations in the composition and flux of volcanic fluids and gases entering the lake. Furthermore, they are modified by the dilution and evaporation effects [1]. Caldera lakes are filled volcanic cavities of two different origins, closely corresponding to the prevailing rock types. The explosive eruptions of high-viscosity, silica-rich magma cause the volcanic cone to rupture, leaving a basin for a future lake. This is the usual origin of andesitic-dacitic, rhyolitic, and peralkaline calderas [1]. The basaltic lavas, on the other hand, are characterized by effusive eruptions [2], thus a caldera can only be formed in them following the collapse of an empty magma chamber $[3,4]$.

On Bali, Indonesia, natural lakes are typically of volcanic origin, usually formed in calderas, like Batur and Bratan Lakes discussed here (Figure 1).

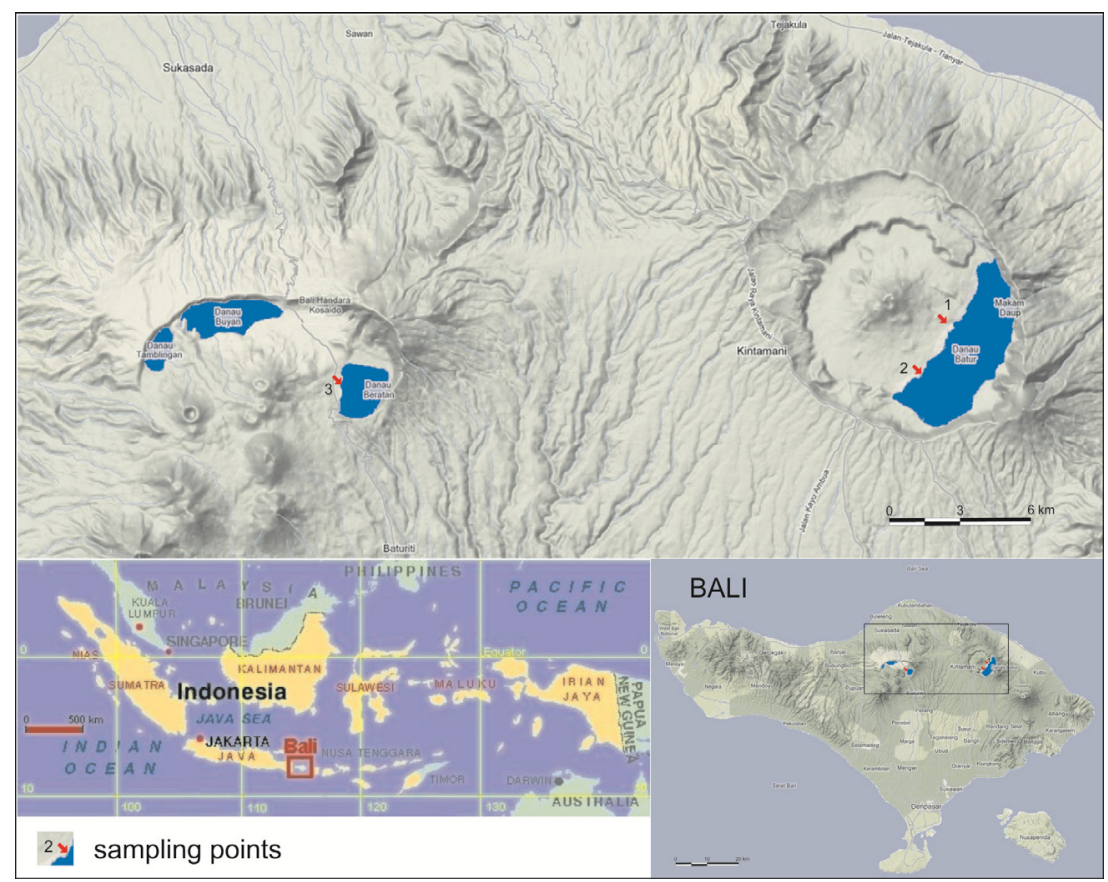

Figure 1. Location of the research area and water sampling points: 1-Batur Lake; 2-Batur Spring; 3-Bratan Lake (Source: www.istp.murdoch.edu.au). 
Both calderas presented in Figure 1 host freshwater lakes but possess different physicochemical characteristics. Batur Lake (15.9 km², $88 \mathrm{~m}$ deep), is four times bigger than Bratan Lake, and is located $200 \mathrm{~m}$ lower. The Batur caldera is also volcanically active, having experienced 28 eruptions since $1800 \mathrm{AD}$, whilst the Bratan caldera has been dormant for at least 200 years (Figure 2). Only the volcanic activity of the nearby Agung caldera can influence the Bratan caldera, however this has been sporadic since $1840 \mathrm{AD}$.

\section{Bali volcano activity}

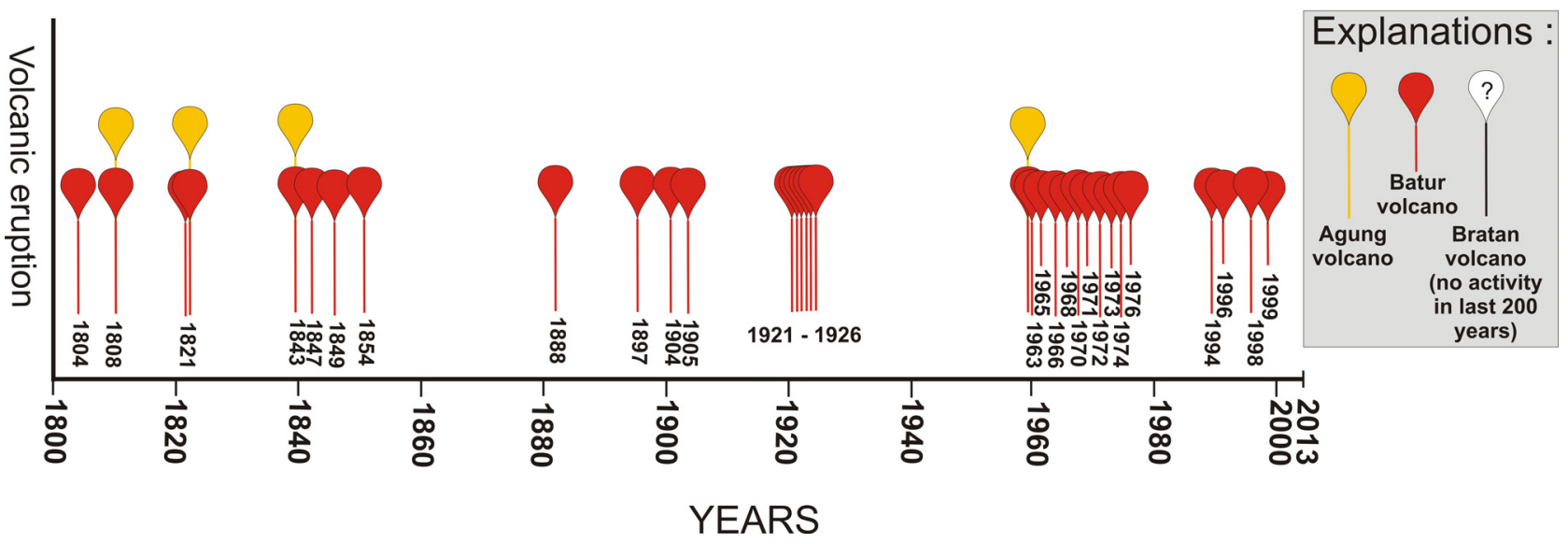

Figure 2. Volcanic activity of volcanoes situated near Batur and Bratan Lakes.

Batur Lake is located at the foot of the Batur volcano, which is $1717 \mathrm{~m}$ high and lies within two concentric, older calderas. These have diameters of 9 and $13 \mathrm{~km}$, and are twenty and thirty thousand years old, respectively. The separate caldera of the Batur Lake, was formed in seven stages. The first pre-caldera reached a height of $3000 \mathrm{~m}$ above sea level and was composed either entirely of basalt or of basalt and andesite. The eruption of the second stage took place around 29,300 BC, introducing dacite and ignimbrite into the local substratum. During the third stage, the formation of the outer caldera occurred. The depression was deeper in the north-western part, causing outflow from an andesite magma reservoir and eruption of silica-rich lava in the fourth stage. The big eruption, alongside outflows of andesite magma through the slits and cracks, occurred during the fifth stage around 20,150 BC, and numerous domes were created. The formation of the inner caldera preceded the emergence of the lake, which took place during the sixth stage. The seventh stage included the formation of a stratovolcano of basalt and andesite in the central part of the caldera [5].

The Buyan-Bratan caldera, located in north-central Bali, is a volcanic complex older than the Batur caldera. The diameter of the structure is around $10 \mathrm{~km}$. There are three lakes and several volcanic cones of the stratovolcanic type inside the inner part of the caldera. The cones are topped with craters which have erupted at least once. Geological interpretation of Buyan-Bratan caldera formation is impeded by its surface being covered with sediment from earlier eruptions of the nearby Batur volcano. One of the few existing pre-caldera Buyan-Bratan sediment exposures is located in the vicinity of the Gitgit waterfall. The sediments are represented by congealed lava with tufas and breccias. In the other part of the caldera there are various rocks represented by basalt and andesite in the form of volcanic sand and gravel breccias. The youngest pumice rocks were created before 23,000 BC. For over 200 years, volcanic eruptions in the caldera have not been recorded [6]. 
The lakes formed in the two calderas are likely to have contrasting characteristics, and we based our sampling methodology for both lakes upon this assumption. Due to the limited time available for conducting this fieldwork, the number of samples was limited to twelve from the caldera lakes and the adjacent spring. However, additional insight into the chemistry of these lakes can be gained from archived data obtained in 1992 and 1993 [4,7]. The sampling sites were selected following a precise morphological analysis of the area, and past chemical and hydrological records.

This paper is a thorough comparison of the chemical composition of these different caldera lakes, which represent different geomorphological characteristics. Since the chemistry of Indonesian equatorial lakes is largely unknown, this study will offer insights into the influence of geothermal processes on lake water chemistry. Furthermore, we also conducted an analysis of organic compounds to distinguish those originating from local biological activity from the typical organic pollutants.

This paper contains the results of the main ionic elements analysis (cations: $\mathrm{Na}^{+}, \mathrm{K}^{+}, \mathrm{Mg}^{2+}, \mathrm{Ca}^{2+}$, and anions: $\mathrm{SO}_{4}{ }^{2-}, \mathrm{F}^{-}, \mathrm{Cl}^{-}, \mathrm{Br}^{-}$), as well as trace elements ( $\mathrm{Li}, \mathrm{B}, \mathrm{Al}, \mathrm{V}, \mathrm{Cr}, \mathrm{Mn}, \mathrm{Co}, \mathrm{Ni}, \mathrm{Cu}, \mathrm{Zn}, \mathrm{As}$, $\mathrm{Se}, \mathrm{Rb}, \mathrm{Sr}, \mathrm{Mo}, \mathrm{Cd}, \mathrm{Sn}, \mathrm{Cs}, \mathrm{Ba}, \mathrm{Pb}, \mathrm{U}, \mathrm{Be}, \mathrm{Ag}, \mathrm{Sb}, \mathrm{Tl}$ and $\mathrm{Bi}$ ). These will be used to confirm the difference in the water source of these volcanic lakes.

\section{Experimental}

\subsection{Field Site}

The research area, Bali $\left(8^{\circ} 25^{\prime} \mathrm{S}, 115^{\circ} 11^{\prime} \mathrm{E}, 563.3 \mathrm{~km}^{2}\right)$, is located in the Indonesian Archipelago within the Lesser Sunda island group. Two large calderas (Mount Batur $1717 \mathrm{~m}$ a.s.1.; Mount Sangiyang $2093 \mathrm{~m}$ a.s.1.) are one of the most prominent landforms in the chain of volcanic mountain ranges on Bali. Batur Lake $\left(17.18 \mathrm{~km}^{2}\right.$ ) and Batur Spring (which are parts of the freshwater lake system of the Mt. Batur caldera) and also Bratan Lake (one of the unconnected lakes situated beside the Mt. Sangiyang caldera), were selected for the study pertaining to the concentration levels of pollutants in this volcanic area located in a tropical climate (Figure 1). Table 1 presents detailed data related to differences between calderas, which need to undergo further discussion.

Table 1. Geochemical and petrological data of rocks and lakes characteristics $[3,7,8]$.

\begin{tabular}{|c|c|}
\hline Bratan Caldera & Batur Caldera \\
\hline \multicolumn{2}{|c|}{ Morphological characteristics } \\
\hline $\begin{array}{c}1231 \mathrm{~m} \text { above sea level, area } 3.8 \mathrm{~km}^{2}, \\
\text { maximum depth } 22 \mathrm{~m}\end{array}$ & $\begin{array}{c}1031 \mathrm{~m} \text { above sea level, area } 15.9 \mathrm{~km}^{2}, \\
\text { maximum depth } 88 \mathrm{~m}\end{array}$ \\
\hline \multicolumn{2}{|c|}{ Volcanic activity } \\
\hline Earlier than around $500 \mathrm{ka} . \mathrm{BP}$ & Around $500 \mathrm{ka} . \mathrm{BP}$ \\
\hline No information about volcanic eruptions & 28 volcanic eruptions (from 1804 to 2000 ) \\
\hline \multicolumn{2}{|c|}{ Geochemistry and petrology of rocks } \\
\hline $\begin{array}{l}\text { - The caldera is composed of basalt and andesite } \\
\text { containing } 45 \%-63 \% \text { silica }\left(\mathrm{SiO}_{2}\right) \text {; } \\
\text { - The outer caldera zone is composed with } \\
\text { dacite and rhyolite containing } 65 \%-72 \% \text { silica; } \\
\text { - Accumulation of minerals such as plagioclase, } \\
\text { pyroxene, magnetite and olivine. }\end{array}$ & $\begin{array}{l}\text { - The caldera is composed of basalt and andesite; } \\
\text { - The erupting magma is of two types, either } \\
\text { basaltic or rhyolitic; } \\
\text { - The magmatic processes are rapid and likely } \\
\text { connected to a shallow supply system. }\end{array}$ \\
\hline
\end{tabular}


Table 1. Cont.

\begin{tabular}{ll}
\hline \multicolumn{1}{c}{ Bratan Caldera } & \multicolumn{1}{c}{ Batur Caldera } \\
\hline \multicolumn{1}{c}{ Lake characteristics } \\
\hline $\begin{array}{l}\text { The shallowest lake on Bali; } \\
\text { strongly influenced by recreational activities, } \\
\text { motor boating and other outdoor activities, }\end{array}$ & - The largest and deepest lake on Bali; \\
hotels and restaurants; & Small-scale agriculture around the lake, and an \\
- Some small-scale agriculture is maintained & built; the lake is used for fisheries; \\
around the lake & - Thermo- and chemostratified, \\
- Thermo- and chemostratified. & - Total biomass: $2.4 \mathrm{mg} \cdot \mathrm{L}^{-1} ;$ \\
- Total biomass: $4.4 \mathrm{mg} \cdot \mathrm{L}^{-1} ;$ & - Transparency ranging $3.0-3.2 \mathrm{~m}$. \\
- Transparency is $1.8 \mathrm{~m}$. & \\
\hline
\end{tabular}

\subsection{Sampling}

All water samples were collected between 23 and 28 January 2013, in $250 \mathrm{~mL}$ plastic bottles for the determination of inorganic compounds and $500 \mathrm{~mL}$ dark glass bottles for organic compound analyses, tightly closed and transported to the laboratory in Gdańsk University of Technology, Poland. Upon arrival at the laboratory, the samples for organic compound determination were frozen.

\subsection{Analytical Methods}

A summary of the analytical techniques, used here to determine the inorganic ions, trace elements and total organic carbon (TOC), is provided in Table 2. The analytical procedures were validated against certified reference materials: Reference Material No. 409 (BCR-409, Institute for Reference Materials and Measurements, Belgium), ANALYTICAL-8 (Inorganic ventures, Christiansburg, VA, USA) and Analytical Reference Material TM-DWS.2 (Environment Canada).

Table 2. Validation parameters and technical specifications of the analytical procedures.

\begin{tabular}{|c|c|c|c|c|c|c|}
\hline Parameter & $\begin{array}{c}\text { Measurement } \\
\text { Range }\end{array}$ & LOD & LOQ & CV (\%) & \multicolumn{2}{|c|}{ Measurement Instrumentation } \\
\hline Cations ${ }^{a, *}$ & $0.03-500$ & 0.01 & 0.030 & 0.9 & \multirow{2}{*}{$\begin{array}{c}\text { DIONEX } 3000 \\
\text { chromatograph } \\
\text { (DIONEX, } \\
\text { Sunnyvale, CA, } \\
\text { USA) }\end{array}$} & $\begin{array}{l}\text { column: Ion Pac }{ }^{\circledR} \mathrm{CS} 14(3 \times 250 \mathrm{~mm}) \text {; } \\
\text { suppressor: CSRS-300, } 2 \mathrm{~mm} \text {, } \\
\text { mobile phase: } 38 \mathrm{mM} \text { metasulfonic } \\
\text { acid, flow rate: } 0.36 \mathrm{~mL} \cdot \mathrm{min}^{-1} \text {, } \\
\text { detection: conductivity }\end{array}$ \\
\hline Anions ${ }^{\mathrm{a}, *}$ & $0.06-500$ & $0.055-0.09$ & $0.027-0.17$ & 0.6 & & $\begin{array}{l}\text { column: Ion Pac }{ }^{\circledR} \text { AS } 22(2 \times 250 \mathrm{~mm}) \text {; } \\
\text { suppressor: ASRS-300, } 2 \mathrm{~mm} \text {, } \\
\text { mobile phase: } 4.5 \mathrm{mM} \mathrm{CO}_{3}{ }^{2-} \text {, } \\
1.4 \mathrm{mM} \mathrm{HCO}{ }^{3-} \text {, flow rate: } \\
0.38 \mathrm{~mL} \cdot \mathrm{min}^{-1} \text {, detection: conductivity }\end{array}$ \\
\hline TOC $\mathrm{a}, *$ & $0.5-500$ & 0.17 & 0.50 & 5.0 & \multicolumn{2}{|c|}{ TOC analyzer (TOC-VCSH/CSN, SHIMADZU, Japan) } \\
\hline Metals ** & $0.002-1000$ & 0.0007 & 0.002 & $0.5-1.5$ & \multicolumn{2}{|c|}{$\begin{array}{l}\text { Elan DRC, PerkinElmer, USA gas fed to the } \\
\text { atomizer } \rightarrow \text { Ar: } 0.98 \mathrm{~L} \cdot \mathrm{min}^{-1} \text {, plasma gas } \rightarrow \text { Ar: } 15 \mathrm{~L} \cdot \mathrm{min}^{-1}\end{array}$} \\
\hline
\end{tabular}

Notes: * $\left(\mathrm{mg} \cdot \mathrm{L}^{-1}\right) ; * *\left(\mu \mathrm{g} \cdot \mathrm{L}^{-1}\right)$; ${ }^{a}$ the measuring range can be extended towards higher concentration ranges

LOD — Limit of detection; LOQ — Limit of quantification; $\mathrm{CV}$ - Coefficient of variance. 
Comprehensive Two-Dimensional Gas Chromatography coupled with Time-of-Flight Mass Spectrometry (GCxGC-TOF/MS) was used to identify a broad spectrum of organic compounds. The analytical procedure of organic compounds' identification consisted of the following steps. After water samples from both lakes were thawed, $500 \mathrm{~cm}^{3}$ of water was taken for examination and mixed with $10 \mathrm{~cm}^{3}$ of dichloromethane (DCM). The extraction was carried out for $2 \mathrm{~h}$, after which the DCM phase was separated from the water phase, to be evaporated to a volume of $0.3 \mathrm{~cm}^{3}$. Its subsample of $2 \mu \mathrm{L}$ volume was injected into the GCxGC-TOF/MS system (LECO, St. Joseph, MO, USA), to enable an analysis with the operating parameters listed in Table 3.

Table 3. The operating parameters of the Comprehensive Two-Dimensional Gas Chromatography coupled with Time-of-Flight Mass Spectrometry (GCxGC-TOF/MS) system.

\begin{tabular}{|c|c|c|}
\hline Inlet & \multicolumn{2}{|c|}{$\begin{array}{l}\text { Carrier Gas: Helium } \\
\text { Inlet Mode: Splitless }\end{array}$} \\
\hline Chromatography columns & \multicolumn{2}{|c|}{$\begin{array}{l}\text { GC1: } 30 \mathrm{~m} \text { ZB-5ms, film thickness } 0.25 \mu \mathrm{m} \text {, inner diameter } 0.25 \mathrm{~mm} \text {. } \\
\text { GC2: } 1.5 \mathrm{~m} \text { BPX50, film thickness } 0.10 \mu \mathrm{m} \text {, inner diameter } 0.1 \mathrm{~mm} \text {. } \\
\text { Postcolumn: } 0.21 \mathrm{~m} \text { BPX50, film thickness } 0.10 \text {, inner diameter } 0.1 \mathrm{~mm}\end{array}$} \\
\hline Oven temperature & $\begin{array}{l}\text { GC1: } \\
\text { Target Temp }\left({ }^{\circ} \mathrm{C}\right): 40 \text { (Initial) } \\
\text { Duration }(\min ): 1.0 \\
\text { Rate }\left({ }^{\circ} \mathrm{C} / \mathrm{min}\right): 7.0 \\
\text { Target Temp }\left({ }^{\circ} \mathrm{C}\right): 230 \\
\text { Duration (min): } 10\end{array}$ & $\begin{array}{l}\text { GC2: } \\
\text { Target Temp }\left({ }^{\circ} \mathrm{C}\right): 70 \text { (Initial) } \\
\text { Duration (min): } 1.0 \\
\text { Rate }\left({ }^{\circ} \mathrm{C} / \mathrm{min}\right): 7.0 \\
\text { Target Temp }\left({ }^{\circ} \mathrm{C}\right): 260 \\
\text { Duration (min): } 10\end{array}$ \\
\hline Modulation parameters & \multicolumn{2}{|l|}{$\begin{array}{l}\text { Modulation Period (s): } 5.0 \\
\text { Hot Pulse Time: } 1.0 \\
\text { Cool Time Between Stages: } 1.5\end{array}$} \\
\hline Mass spectrometer settings & \multicolumn{2}{|c|}{$\begin{array}{l}\text { Start Mass }(\mathrm{u}): 33 \\
\text { End Mass }(\mathrm{u}): 400 \\
\text { Acquisition Rate (spectra/second): } 200 \\
\text { Ion Source Temperature }\left({ }^{\circ} \mathrm{C}\right): 250 \\
\end{array}$} \\
\hline Library & \multicolumn{2}{|c|}{ NIST 2011, contains 243,893 spectra of 212,961 compounds. } \\
\hline
\end{tabular}

\section{Results and Discussion}

The specific physical processes influencing the chemical composition of Indonesian equatorial lakes are largely underexplored. The general setting suggests a stability of wind directions for prolonged periods and the likely important role of biological and geothermal processes [7]. The lake density structure depends on the gradients of total dissolved solids since temperature gradients are relatively small. Biologically induced stratification preserved by the salinity gradient seems to be of great importance, as well as deep thermal gradients which may be adiabatic and stable. Geothermal heating is likely to exceed the adiabatic gradient. Hot springs are likely to flow into the lakes, and in the case of Batur Lake, there is a thermal Batur spring. Seepage, rainfall and evaporation are their main sources of water supply. Changes in the mixing depth caused by the weather and depth of seasonal mixing may influence the nutrient flux into the epilimnion zone. Incomplete vertical mixing of lakes is highly dependent on the relative depth (or area) and how exposed they are to wind [7]. 
Tables 4 and 5 present the results of the research.

Table 4. Average concentrations of main elements analyzed in water samples from Batur Lake, Thermal Batur Spring and Bratan Lake [4,7].

\begin{tabular}{cccccccc}
\hline $\begin{array}{c}\text { Determined } \\
\text { Parameter } \\
\left(\mathbf{m g} \cdot \mathbf{L}^{-1}\right)\end{array}$ & \multicolumn{3}{c}{ Batur Lake } & & Batur Spring & Bratan Lake & $\begin{array}{c}\text { Major } \\
\text { Reservoirs in } \\
\text { Indonesia }\end{array}$ \\
\hline $\mathrm{Year}$ & 2013 & 1992 & 1993 & 2013 & 2013 & 1993 & $1989-1995$ \\
$\mathrm{pH}$ & 8.54 & 8.5 & 8.8 & 7.37 & 7.00 & - & $6.8-8.8$ \\
$\mathrm{EC}{ }^{1}(\mu \mathrm{S} / \mathrm{cm})$ & 1,730 & - & $1.750-1.800$ & 1,609 & 27.9 & $22-27$ & $22-1,811$ \\
$\mathrm{Na}^{+}$ & 287 & 355 & 350 & 248 & 3.40 & 1.3 & $1.3-350$ \\
$\mathrm{~K}^{+}$ & 55.7 & 31 & 22 & 55.3 & 0.388 & 0.45 & $0.45-22$ \\
$\mathrm{Mg}^{2+}$ & 26.9 & 68 & 0.62 & 23.8 & 1.87 & 0.85 & $0.87-1,280$ \\
$\mathrm{Ca}^{2+}$ & 18.2 & 35 & 35 & 29.6 & 0.082 & 1.9 & $1.9-32$ \\
$\mathrm{SO}_{4}^{2-}$ & 394 & 491 & $650-670$ & 287 & 1.85 & $0.35-0.50$ & $0.35-49,350$ \\
$\mathrm{~F}^{-}$ & 2.71 & 0.86 & - & 2.73 & 0.504 & - & - \\
$\mathrm{Cl}^{-}$ & 165 & 237 & 225 & 144 & 1.15 & 1.5 & $1.0-26,700$ \\
$\mathrm{Br}^{-}$ & 0.723 & - & - & 0.881 & 0.118 & - & - \\
$\mathrm{Total}^{-} \mathrm{N}$ & 0.22 & - & $0.256-0.970$ & 3.39 & 0.030 & $0.310-1.310$ & $0.116-1.310$ \\
$\mathrm{Total} \mathrm{P}$ & 2.03 & - & 0.028 & 2.08 & 0.360 & 0.002 & $0-0.080$ \\
\hline
\end{tabular}

Note: ${ }^{1}$ EC-Electrical conductivity.

Table 5. Average concentrations of trace elements analyzed in water samples from Batur Lake, the thermal Batur Spring, and Bratan Lake and rocks $[7,9,10]$.

\begin{tabular}{|c|c|c|c|c|c|c|c|}
\hline $\begin{array}{c}\text { Determined } \\
\text { Parameter }\left(\mu \mathrm{g} \cdot \mathbf{L}^{-1}\right)\end{array}$ & $\begin{array}{c}\text { Batur } \\
\text { Lake } 2013\end{array}$ & $\begin{array}{c}\text { Batur } \\
\text { Spring } 2013\end{array}$ & $\begin{array}{c}\text { Batur } \\
1992\end{array}$ & $\begin{array}{c}\text { Batur } \\
1993\end{array}$ & $\begin{array}{l}\text { Batur } \\
\text { Rocks } \\
\text { (ppm) } \\
\end{array}$ & $\begin{array}{c}\text { Bratan } \\
\text { Lake } 2013\end{array}$ & $\begin{array}{c}\text { Major } \\
\text { Reservoirs in } \\
\text { Indonesia } \\
\end{array}$ \\
\hline $\mathrm{Li}$ & 423 & 361 & 400 & & & $<\mathrm{LOD}$ & \\
\hline B & 1440 & 2035 & 1490 & & & 53 & \\
\hline $\mathrm{Al}$ & 2.4 & 1.1 & & & & 8.0 & \\
\hline V & 34.8 & 80.0 & & & $5.7-309$ & 0.4 & \\
\hline $\mathrm{Cr}$ & 3.8 & 6.2 & & n.d. ${ }^{1}$ & $1.5-29$ & 0.5 & n.d. ${ }^{1}$ \\
\hline $\mathrm{Mn}$ & 0.4 & $<$ LOD & & & & 0.4 & $0-0.14$ \\
\hline Co & $<$ LOD & $<\mathrm{LOD}$ & & & $2-45$ & $<$ LOD & \\
\hline $\mathrm{Ni}$ & $<$ LOD & $<\mathrm{LOD}$ & & n.d. ${ }^{1}$ & $2.0-43$ & $<\mathrm{LOD}$ & n.d. ${ }^{1}$ \\
\hline $\mathrm{Cu}$ & 2.2 & 2.6 & & n.d. ${ }^{1}$ & $7.4-139$ & 0.4 & n.d. ${ }^{1}$ \\
\hline $\mathrm{Zn}$ & 1.7 & 2.3 & & $0-0.34$ & & 1.0 & $0-0.30$ \\
\hline As & 4.1 & 29.2 & & & & 0.2 & \\
\hline $\mathrm{Se}$ & 0.94 & 3.80 & & & & $<\mathrm{LOD}$ & \\
\hline $\mathrm{Rb}$ & 62.7 & 67.9 & & & $18-45$ & 3.33 & \\
\hline $\mathrm{Sr}$ & 96 & 140 & 1500 & & $168-484$ & 11 & \\
\hline Mo & 3.15 & 5.76 & & & $0.6-2.2$ & $<\mathrm{LOD}$ & \\
\hline $\mathrm{Cd}$ & $<$ LOD & $<$ LOD & & n.d. ${ }^{1}$ & & $<$ LOD & n.d. ${ }^{1}$ \\
\hline $\mathrm{Sn}$ & $<\mathrm{LOD}$ & 0.50 & & & & $<\mathrm{LOD}$ & \\
\hline Cs & 3.13 & 4.29 & & & $0.3-2.5$ & 0.04 & \\
\hline $\mathrm{Ba}$ & 11.2 & 4.70 & & & $168-504$ & 2.2 & \\
\hline $\mathrm{Pb}$ & $<\mathrm{LOD}$ & $<\mathrm{LOD}$ & & n.d. ${ }^{1}$ & $3.3-12.9$ & $<\mathrm{LOD}$ & n.d. ${ }^{1}$ \\
\hline $\mathrm{U}$ & 0.113 & 0.474 & & & $0.4-1.7$ & $<\mathrm{LOD}$ & \\
\hline $\mathrm{Be}, \mathrm{Ag}, \mathrm{Sb}, \mathrm{Tl}, \mathrm{Bi}$ & $<\mathrm{LOD}$ & $<$ LOD & & & & $<\mathrm{LOD}$ & \\
\hline
\end{tabular}




\subsection{Main Elements}

The results obtained with the use of analytical techniques (including GCxGC) indicate striking differences in the chemical composition of the water between the two lakes. The chemical parameters of the water samples obtained during the study are listed in Table 4, combined with data obtained from literature. The electrical conductivity (EC) in natural Indonesian lakes of varying origin (caldera, tectonic, tectonic/volcanic, floodplain, semi-natural, landslide, volcanic/crater, crater) was usually within the range of $80-300 \mu \mathrm{S} \cdot \mathrm{cm}^{-1}$. Generally, the EC value decreases slightly with the increasing depth of a lake (Figure 3). However, this is not obvious for all caldera lakes. In Batur and Bratan Lakes, there were two extremes observed: 1730 and $27.9 \mu \mathrm{S} \cdot \mathrm{cm}^{-1}$, respectively. Such values were earlier observed in 1993 for Batur Lake $\left(1750-1800 \mu \mathrm{S} \cdot \mathrm{cm}^{-1}\right)$ and for Bratan Lake $\left(22-27 \mu \mathrm{S} \cdot \mathrm{cm}^{-1}\right)$ [7]. Particularly low EC values observed in Bratan Lake may result from a short retention time of rainwater supplying this lake.

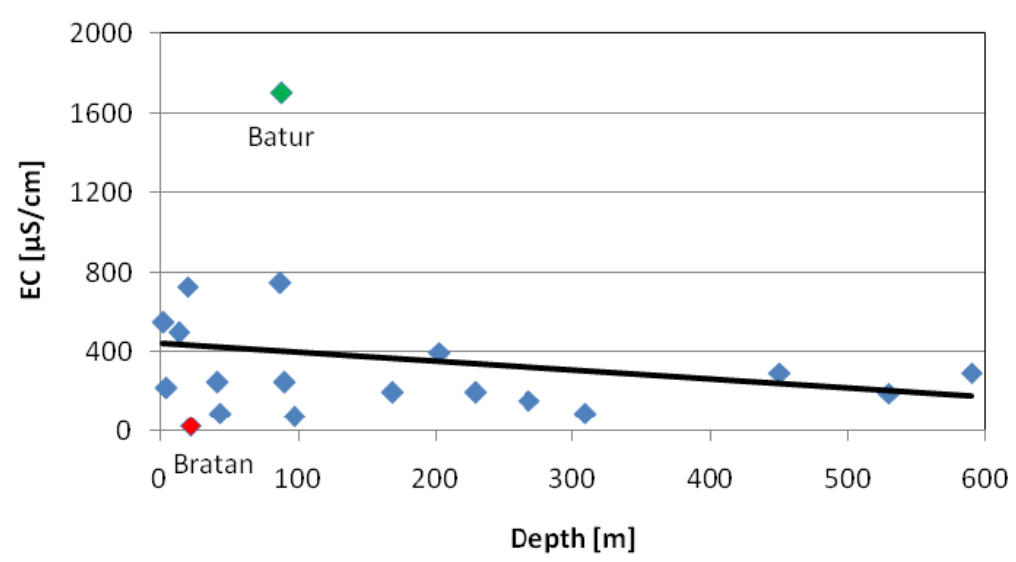

Figure 3. Batur and Bratan within the spectrum of electrical conductivities (EC) experienced in Indonesian lakes.

The concentration levels of the main ions and conductivity of Batur Spring water are very similar to Batur Lake water. The slope coefficient of a regression curve (between Batur Lake and Batur Spring) is close to one $(0.926)$ for a very high correlation coefficient $\mathrm{R}^{2}(0.997)$, the linear regression parameters of ions $\left(\mathrm{Na}^{+}, \mathrm{K}^{+}, \mathrm{Mg}^{2+}, \mathrm{Ca}^{2+}, \mathrm{SO}_{4}{ }^{2-}, \mathrm{F}^{-}, \mathrm{Cl}^{-}\right.$and $\left.\mathrm{Br}^{-}\right)$concentrations and electrical conductivity in the three studied sites (Table 6). A similar EC value $\left(1609 \mu \mathrm{S} \cdot \mathrm{cm}^{-1}\right)$ appears for the thermal Batur Spring. Batur Lake is both thermo- and chemostratified, although its studies were conducted only to the depth of $50 \mathrm{~m}$. It is the most saline $\left(165 \mathrm{mg} \cdot \mathrm{Cl}^{-} \mathrm{L}^{-1}\right)$ of the studied lakes and has a high $\mathrm{pH}$ of $8.54(\mathrm{pH}=8.8$ in 1993 [7]), especially in the epilimnion zone. The research literature shows that $\mathrm{pH}$ of the epilimnion zone in the Indonesian lakes ranged from 6.8 to 8.8 [9]. The usually high $\mathrm{pH}$ values also affect carbon dioxide equilibria, probably due to a relatively high daytime algal production. The values of $\mathrm{pH}$ for Bratan Lake and Batur Spring differ significantly (7.00 and 7.37, respectively). Bratan Lake is also thermo- and chemostratified but its water is the most diluted of all the Indonesian lakes. Its salinity at the level of $1.15 \mathrm{mgCl}^{-} \cdot \mathrm{L}^{-1}$ is 100 times lower than in Batur Lake and the thermal Batur Spring. In Indonesia, the concentration of chloride ions in lake water can fall within the range of 1.5 to $225 \mathrm{mg} \cdot \mathrm{L}^{-1}$ and largely depends on their origin, and thereby the depth and surface area of a lake [7]. 
Table 6. The linear regression parameters of $\mathrm{Na}^{+}, \mathrm{K}^{+}, \mathrm{Mg}^{2+}, \mathrm{Ca}^{2+}, \mathrm{SO}_{4}^{2-}, \mathrm{F}^{-}, \mathrm{Cl}^{-}$and $\mathrm{Br}^{-}$ concentrations and electrical conductivity in the studied sites.

\begin{tabular}{ccc}
\hline Compared Data & Regresion Curve & $\boldsymbol{R}^{\mathbf{2}}$ \\
\hline Batur Lake/Batur Spring & $y=0.926 x-9.02$ & 0.997 \\
Batur Lake/Bratan Lake & $y=0.016 x-0.591$ & 0.965 \\
Batur Spring/Bratan Lake & $y=0.017 x-0.464$ & 0.980 \\
\hline
\end{tabular}

Alkaline cations, especially calcium and magnesium, appeared mainly as a result of the ion exchange processes with the magma creating the calderas, as a mechanism of weathering [3]. Calcium concentrations in the Indonesian lakes were usually between 1.9 and $35 \mathrm{mg} \cdot \mathrm{L}^{-1}$. The lowest concentration determined during the research was around 20 times lower in Bratan Lake $\left(0.082 \mathrm{mg} \cdot \mathrm{L}^{-1}\right)$ and the highest concentration was in Batur Lake $\left(18.2 \mathrm{mg} \cdot \mathrm{L}^{-1}\right)$ and Batur Spring (around $29.6 \mathrm{mg} \cdot \mathrm{L}^{-1}$ ). Magnesium concentrations in the Indonesian lakes ranged from 4.0 to $10.0 \mathrm{mg} \cdot \mathrm{L}^{-1}$. For both caldera lakes, the values of $\mathrm{Mg}^{2+}$ concentrations differ by an order of magnitude. In comparison to 1993, there was a significant increase in the content of these ions in the water of Batur Lake from $0.62 \mathrm{mg} \cdot \mathrm{L}^{-1}$ to 26.9 in 2013, whereas for Bratan Lake this value only doubled [7]. The increase in $\mathrm{Ca}^{2+}$ and $\mathrm{Mg}^{2+}$ concentrations in lake water can be connected with soil acidification, resulting in a higher export of these elements into water.

In the Indonesian lakes, potassium usually ranged from 0.5 to $3.0 \mathrm{mg} \cdot \mathrm{L}^{-1}$ and generally there were no distinct vertical differences. However, during the research conducted on the samples from Batur Lake and Spring, $\mathrm{K}^{+}$was determined and the concentration of $\mathrm{K}^{+}$amounted to $55 \mathrm{mg} \cdot \mathrm{L}^{-1}$, which is 150 times higher than in Bratan Lake. During the research from 1993, the $\mathrm{K}^{+}$concentration for Batur Lake was $22 \mathrm{mg} \cdot \mathrm{L}^{-1}$ and then increased by $150 \% . \mathrm{K}^{+}$is an essential component of acidic effusive rocks which form calderas (rhyolite), but its increase can also be caused by the growing use of natural and mineral potassium fertilizers in the fields surrounding the lake. Sodium levels ranged from $3.4 \mathrm{mg} \cdot \mathrm{L}^{-1}$ (Bratan) to about $300 \mathrm{mg} \cdot \mathrm{L}^{-1}$ (Batur), while for other lakes in Indonesia these values were about $1.5-18.0 \mathrm{mg} \cdot \mathrm{L}^{-1}$ [7]. The research carried out in $2013 \mathrm{did}$ not show any significant deviation from the published data for the years 1992-1993, which suggests the main ions to be of generally stable composition in the waters of both lakes.

Sulfate concentrations of the natural lakes are expected to be high due to volcanic surroundings. Minor eruptions and hot springs are permanent sources of sulfate influx in the area that should be particularly significant in Batur Lake, which is subject to current volcanic activity. The contrastingly high concentrations in Batur $\left(650-670 \mathrm{mg} \cdot \mathrm{L}^{-1}\right)$ and low concentrations in Bratan $\left(0.35-0.50 \mathrm{mg} \cdot \mathrm{L}^{-1}\right)$ confirmed this assumed pattern. However, since 1989, a continual decrease of $\mathrm{SO}_{4}{ }^{2-}$ concentration to the present level of $394 \mathrm{mg} \cdot \mathrm{L}^{-1}$ has been observed in Batur Lake, which may be an indication of decreasing volcanic activity in this period. In most natural Indonesian lakes, concentrations ranged from 1.0 to $3.0 \mathrm{mg} \cdot \mathrm{L}^{-1}[7,10]$.

Nutrient concentrations in Indonesian lakes are typically low, especially in natural lakes, however a relative increase in their concentration is observed in deeper lakes. The concentrations in reservoirs are, surprisingly, at a similar level, despite agricultural and populated areas contributing to their catchments, but this may be due to wetlands and rice paddies acting as efficient nitrogen traps. 
Similarly to nitrogen, the total phosphorus (total P) concentrations were rather low. This is also typical of the area since Indonesian soils are deficient in phosphorus. The highest total nitrogen (total $\mathrm{N}$ ) value was observed in 1993 in Bratan Lake $\left(1.310 \mathrm{mg} \cdot \mathrm{L}^{-1}\right)$, whereas the highest total phosphorus concentration was only $0.085 \mathrm{mg} \cdot \mathrm{L}^{-1}$ and was noted in another Indonesian lake, named Ranau [7]. Generally, total phosphorus values in Indonesian lakes did not exceed $0.1 \mathrm{mg} \cdot \mathrm{L}^{-1}$ and slightly declined with the increasing lake depth (Figure 4). However, the conducted research indicates a significant increase in the total $\mathrm{P}$ value both in the Batur Lake caldera and the Batur Spring, within the 20 year period since the last survey. This may be a result of the growing use of surfactants (containing phosphates) in households (intensified tourism development). The observed variations in total $\mathrm{P}$ concentrations are likely to be due to soil acidification (fertilization) and expanding phosphorus export into water, which intensifies eutrophication. This is an important change, since in 1993 eutrophication in Indonesian lakes was a very rare occurrence [7].

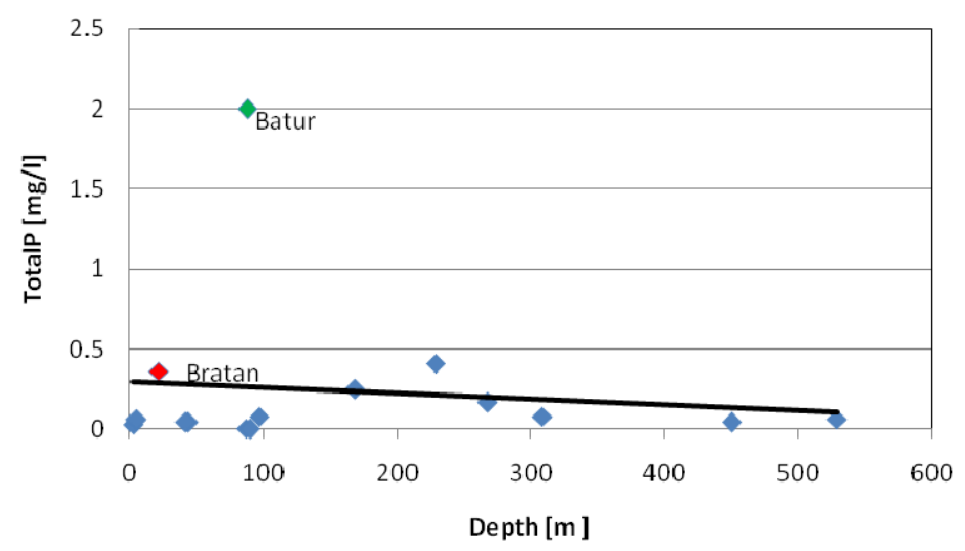

Figure 4. Relationship between the total phosphorus (total P) concentrations (highest values) and the depth in natural Indonesian lakes.

In 1993, the N:P-ratio for total nitrogen and total phosphorus in natural lakes was as expected, although they ranged from 1.9 to 485 , and the particularly high ratios occurred due to low phosphorus concentrations. At present, high total $\mathrm{P}$ values make the N:P ratio 0.11 for Batur Lake and 0.083 for Bratan Lake, which is very low as compared to values from the 1993 survey, and indicates nitrogen limitation of their ecosystems. In this type of ecosystem, cyanobacterial blooms have a competitive advantage over other algal groups because of their nitrogen fixing abilities, and high $\mathrm{P}$ levels $(>1 \mathrm{mg} / \mathrm{L})$ may cause their intense blooms. This again follows from the important difference between the levels of phosphorus in these two lakes today, compared to an Indonesia-wide survey conducted in 1993, and is likely to be associated with current pollution. Therefore, nutrient regimes of Indonesian equatorial lakes should receive more attention, especially in respect to phosphorus.

\subsection{Trace Elements}

In 1993, heavy metals (cadmium, chromium, copper, nickel and lead) were not detected in Indonesian lakes. Only zinc concentrations were detected, and varied in natural lakes from undetectable to $0.34 \mathrm{mg} \cdot \mathrm{L}^{-1}$ in Batur Lake [7]. At present, the majority of metal ions, including heavy 
metals, are detected and determined (Table 5). This is again a shift towards significantly higher pollutant levels than 20 years ago, which requires urgent attention from the local government.

The speciation of metals is modified by the environmental, physico-chemical factors such as $\mathrm{pH}$, the presence of complexing ligands (humic and fulvic acids, chlorides, sulphates, carbonates or phosphates) and other metal ions. For the $\mathrm{pH}$ value of around 7 (for example in Bratan Lake) heavy metals occur in bioavailable and toxic forms. Humic and fulvic acids, chlorides, sulphates, carbonates or phosphates can also create stable complexes with metals. Such considerations on the influence of $\mathrm{pH}$ on the presence of trace elements have already been described for the Ijen caldera (Indonesia) [9].

Figure 5 shows the different characteristics of the analyzed trace elements, which can be related to their different sources and post-depositional paths, under conditions of various $\mathrm{pH}$ and organic compound concentration levels. The points circled in Figure 5 represent elements such as $\mathrm{Cu}, \mathrm{Zn}, \mathrm{Mn}$, $\mathrm{Cr}$, As, Se and U, which showed similar concentrations in both lakes. However, elements such as $\mathrm{Rb}$ and Sr, which occurred in high concentrations in Batur Lake, can be linked to volcanic activity (see Figure 2). From 1993 to 2013, the concentrations of these elements in Batur Lake have decreased slightly, which is consistent with the lack of fresh volcanic eruptions in the caldera during this period.

Batur/Bratan

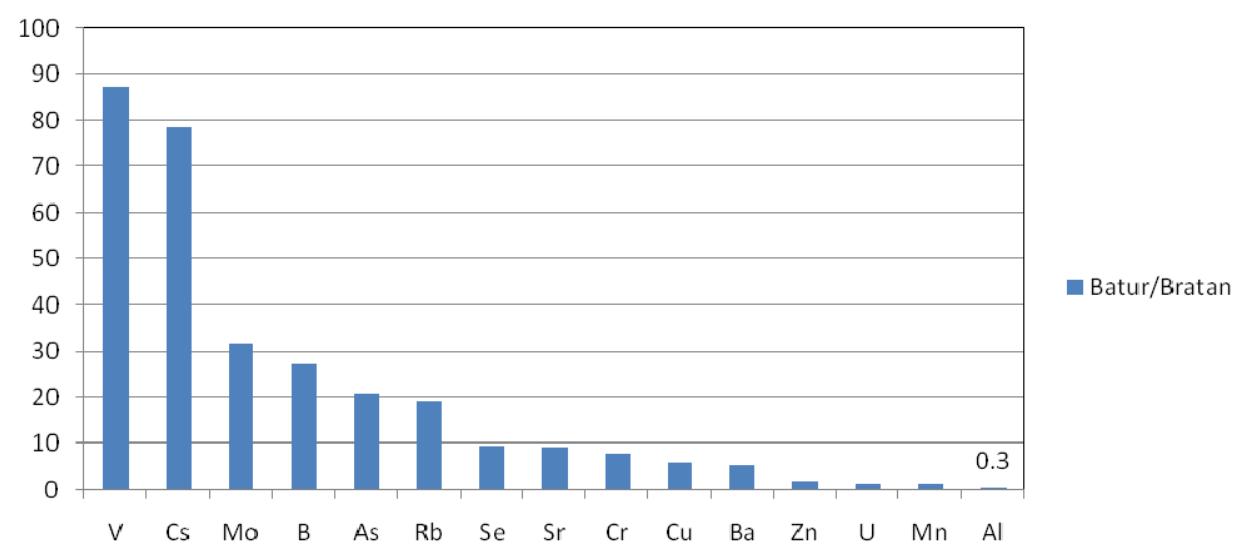

Figure 5. Relationship between the concentrations of chosen trace elements in both caldera lakes and the ratio of the given trace element concentration in Batur Lake to their concentration in Bratan Lake.

A decrease in the $\mathrm{pH}$ of lake water (for example from 8.8 to 8.54 at Batur Lake) influences the change in solubility and oxidation state of many metals. Under these mildly acidic conditions, the solubility of particularly $\mathrm{Al}, \mathrm{Cu}, \mathrm{Zn}, \mathrm{Ni}$ and $\mathrm{Pb}$ has increased, while that of $\mathrm{V}$ decreased.

The bar chart in Figure 5 shows that the relationship between Al concentrations in both caldera lakes is significantly different from the relationships of other trace elements. The Al concentration for Bratan Lake is much higher $\left(8.0 \mu \mathrm{g} \cdot \mathrm{L}^{-1}\right.$ for $\left.\mathrm{pH} 7.00\right)$. The growing Al solubility can lead to the appearance of toxic ions, which may result in impoverishment of the local fauna and flora. Al can also precipitate in complexes with humic substances so that the water in a reservoir can become more transparent but harmful to animals, plants and human health.

Elements such as $\mathrm{V}, \mathrm{Cr}, \mathrm{Co}, \mathrm{Ni}, \mathrm{Cu}, \mathrm{Rb}, \mathrm{Sr}, \mathrm{Mo}, \mathrm{Cs}, \mathrm{Ba}, \mathrm{Pb}$ or $\mathrm{U}$, which were detected and determined in the water of Batur Lake, are also present in volcanic gas plumes and rock obtained from the substrates (Table 2). The elements determined in the water of the lakes situated in the calderas also 
contained minerals creating these calderas: Al (Plagioclase), Li (Pyroxene), V (Vanadium), Cr (Magnetite), and Ni (Olivine). Hydrothermal fluids, with element ratios that are different from those in host rocks, either precipitated secondary phases during their history, or were formed by an incongruent dissolution of volcanic rock during water-rock interaction. The main rock-derived elements in volcanic lake fluids from andesitic volcanoes are $\mathrm{Na}, \mathrm{Ca}, \mathrm{K}, \mathrm{Mg}$ and $\mathrm{Al}$, which are derived from the dissolution of volcanic glass, plagioclase, pyroxene and biotite or muscovite [10-12].

Table 7 presents the regression curve and correlation coefficients. The curve directional factor while comparing trace elements in Batur Lake and Batur Spring water is 1.37 for the high correlation coefficient $\mathrm{R}^{2}$ (0.987). It is another indication that the basic inflow source for Batur Lake is Batur Spring water, with its high content of ionic and trace elements.

Table 7. Linear regression parameters of trace element ( $\mathrm{Li}, \mathrm{B}, \mathrm{Al}, \mathrm{V}, \mathrm{Cr}, \mathrm{Mn}, \mathrm{Co}, \mathrm{Ni}, \mathrm{Cu}$, $\mathrm{Zn}, \mathrm{As}, \mathrm{Se}, \mathrm{Rb}, \mathrm{Sr}, \mathrm{Mo}, \mathrm{Cd}, \mathrm{Sn}, \mathrm{Cs}, \mathrm{Ba}, \mathrm{Pb}, \mathrm{U}$ ) comparisons between field sites.

\begin{tabular}{ccc}
\hline Compared Data & Regresion Curve & $\boldsymbol{R}^{\mathbf{2}}$ \\
\hline Batur Lake/Batur Spring & $y=0.926 x-9.02$ & 0.997 \\
Batur Lake/Bratan Lake & $y=0.016 x-0.591$ & 0.965 \\
Batur Spring/Bratan Lake & $y=0.017 x-0.464$ & 0.980 \\
\hline
\end{tabular}

\subsection{TOC and Organic Compounds}

Many publications hypothesize that the loss of dissolved organic matter from lake water is connected with their acidification, although the acidification itself may also be caused by the presence of humic compounds. Their concentration can be approximated using the total organic carbon (TOC) concentration levels [13-16].

A noticeable correlation has also been suggested between the TOC content and elevation above sea level [17]; the higher the altitude, the lower the TOC content in lakes. The TOC values for water from the two caldera lakes, differing in altitude by $200 \mathrm{~m}$, is in stark contrast with the Batur Lake achieving a TOC concentration of $53.5 \mathrm{mg} \cdot \mathrm{L}^{-1}$ (Batur Spring reached $80.0 \mathrm{mg} \cdot \mathrm{L}^{-1} \mathrm{TOC}$ ), and Bratan Lake showing a relatively small TOC content of $4.09 \mathrm{mg} \cdot \mathrm{L}^{-1}$. The water of the higher situated, Bratan Lake, had a lower $\mathrm{pH}$ and TOC than the water of Batur Lake.

The total biomass amounts for Batur and Bratan Lake were $2.4 \mathrm{mg} \cdot \mathrm{L}^{-1}$ and $4.4 \mathrm{mg} \cdot \mathrm{L}^{-1}$, respectively, and these data correspond with the transparency of water (from 3.0 to $3.2 \mathrm{~m}$ for Batur and $1.8 \mathrm{~m}$ for Bratan). These small biomass values, and low nutrient levels, make the local ecosystem more vulnerable to small chemical changes [7]. Hence, the pollution with trace metals described here may be an important factor influencing the local biota. Interestingly, the total biomass in these lakes showed an opposite direction of changes to the TOC, perhaps implying that an important part of the TOC originates from human-induced pollution.

The analysis of DCM extracts from the caldera lake water was carried out with the use of a GCxGC-TOF/MS system. As a result of the separation of compounds contained in DCM extracts with a comprehensive two-dimensional gas chromatography, very detailed chromatograms were obtained (around 800-900 chromatographic peaks). These are presented in Figure 6, where parts A-D show intervals of retention time in the second column of the GcxGC-TOF/MS system. 
These were cross-checked against a control sample (blank). A few of the peaks present in blanks also occurred in the samples, although their intensity was significantly higher than in the blanks. It may suggest that these compounds are also present in the sample. Aliphatic hydrocarbons, alcohols, ketones, aldehydes, organochlorides, organobromine and organoiodine compounds, and fatty acids were among the identified compounds. A considerable number of compounds (around 35\%-40\%) present such a complicated mass spectrum that their identification by means of comparing to spectrums from the NIST 2011 library does not allow us to define their structure with an appropriate probability. Table 8 shows a list of compounds identified in the samples which were not present in blanks.
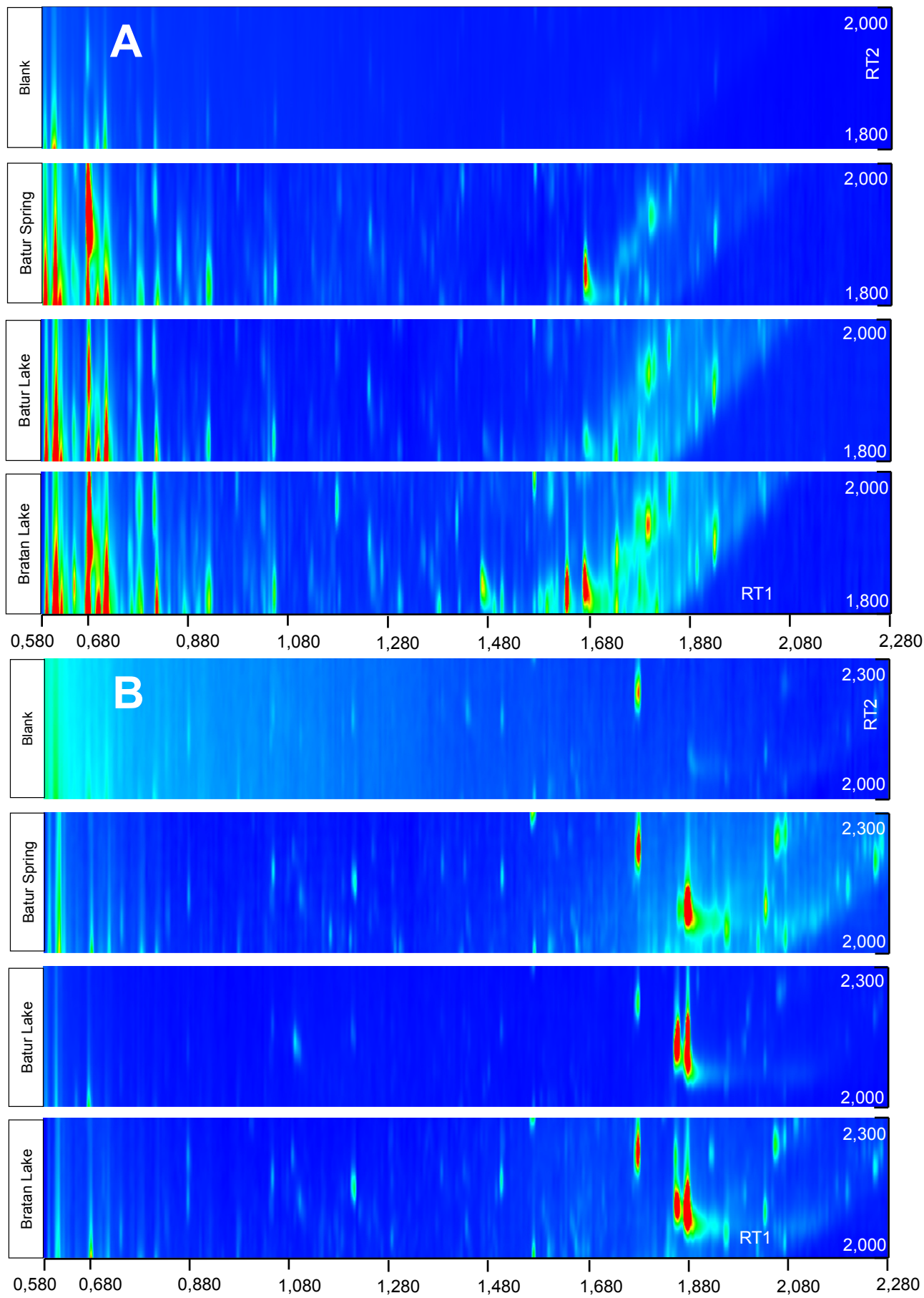

Figure 6. Cont. 

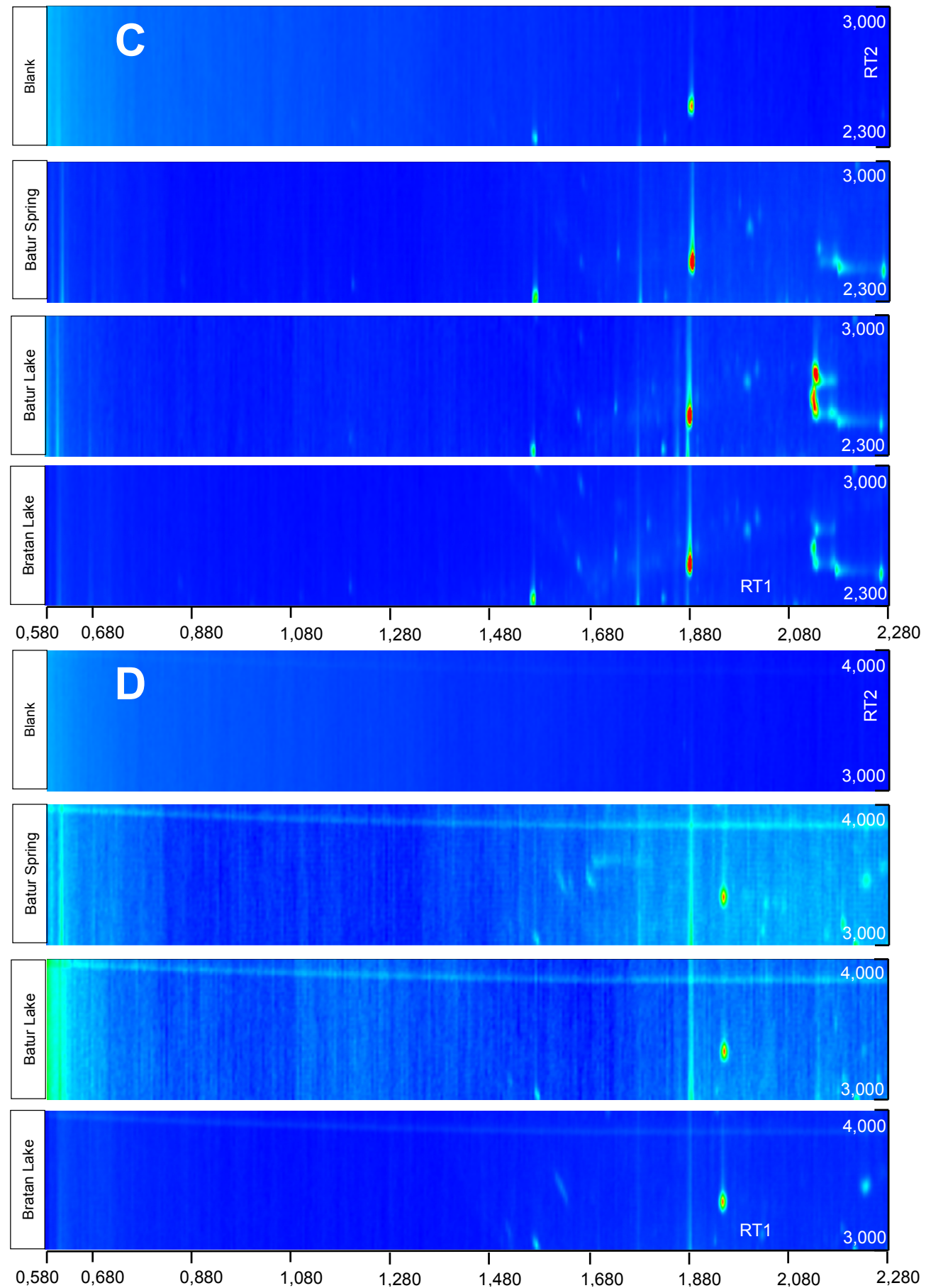

Figure 6. GCxGC-MS/TOF chromatograms of the dichloromethane (DCM) extracts, of the following samples from top to bottom: blank, Batur Spring, Batur Lake, Bratan Lake water. Sections A-D show intervals of retention time on the second column of the system: (A): 1800-2000 s; (B): 2000-2300 s; (C): 2300-3000 s; (D): 3000-4000 s. Several peaks visible in Figure 6 stem from the extract preparation protocol (the applied solvent-DCM, the employed glass, and the procedure of extract evaporation). 
Table 8. A list of compounds identified in the samples which were not present in blanks.

\begin{tabular}{cccccc}
\hline Compounds Identified & $\begin{array}{c}\text { Retention Time } \\
\text { RT1; RT2 }\end{array}$ & Blank & $\begin{array}{c}\text { Batur } \\
\text { Lake }\end{array}$ & $\begin{array}{c}\text { Batur } \\
\text { Spring }\end{array}$ & $\begin{array}{c}\text { Bratan } \\
\text { Lake }\end{array}$ \\
\hline RT: $1650-1800$ & & & & \\
\hline Halocarbons & & + & +++ & +++ & +++ \\
\hline 2-(dodecyloxy)-ethanol & RT: $1800-2000$ & & & & \\
Tetradecanoic acid (Myristic acid) & $1630 ; 1830$ & - & + & + & +++ \\
trans-2-Undecen-1-ol & $1665 ; 1845$ & - & - & - & +++ \\
\hline R-butyldihydro-2(3H)-furanone & $1725 ; 1845$ & - & - & - & - \\
\hline cis-9-Hexadecenoic acid & $1115 ; 2140$ & - & + & - & - \\
Hexadecanoic acid & $1855 ; 2150$ & - & +++ & + & +++ \\
Diethylene glycol monododecyl ether & $1875 ; 2155$ & - & +++ & +++ & +++ \\
3-Heptadecanone & $1920 ; 2225$ & - & - & - & + \\
\hline Dibutyl phthalate & $2070 ; 2260$ & - & - & + & + \\
2-methyl-Eicosane & RT2: $2300-3000$ & & & & \\
Oleic Acid & $1880 ; 2505$ & - & +++ & +++ & +++ \\
9,12,15-Octadecatrienoic acid & $1995 ; 2675$ & - & + & + & + \\
Dodecanamide & $2130 ; 2550$ & - & +++ & + & + \\
Heptadecyl acetate & $2135 ; 2710$ & - & +++ & + & + \\
& $2210 ; 2990$ & - & - & + & - \\
\hline Hexanedioic acid, & $2265 ; 2460$ & - & + & + & + \\
\hline mono-(2-ethylhexyl)-ester & $1945 ; 3345$ & - & + & + & + \\
\hline
\end{tabular}

Notes: Compounds: not present in the sample(-); present in trace amounts(+); present at relativety high level(+++).

The broad profile of organic compounds found in both lakes was similar. The presence of fatty acids such as tetradecanoic acid (myristic acid, 14:0), hexadecanoic acid (palmitic acid, C16:0), octadecanoic (stearic acid, 18:0), 9Z-octadecenoic acid (oleic acid, 18:1), and 9,12,15-octadecatrienoic acid (linonenic acid, 18:3) is characteristic of the tested samples. The occurrence of fatty acids in the researched water is most probably connected with the presence of bacteria, including cyanobacteria, which are widely distributed in the free-living state and can be encountered in almost every habitat on the Earth. These bacteria are resistant to high salinity or acidity, prolonged droughts and high temperatures of hot springs. Cyanobacteria are able to produce a variety of fatty acids, but predominantly, it is the hexadecanoic acid, usually present at the level of $24 \%-40 \%$ of total fatty acids [18]. Hexadecanoic acid occurs in all tested samples collected from both Batur and Bratan Lakes and Batur Spring. Its concentration is relatively high and similar in all samples (Figure 7). There might be other sources of its origin, e.g., coconut palms.

Despite the general similarities, a range of organic compounds' concentrations distinguished the two lakes from one another. The deep waters of Batur Lake contain much higher oleic and linonenic acid concentrations than those observed in the waters of Bratan Lake. Myristic acid (14:0) was only identified in Bratan Lake and neither was observed in Batur Lake nor Batur Spring. 


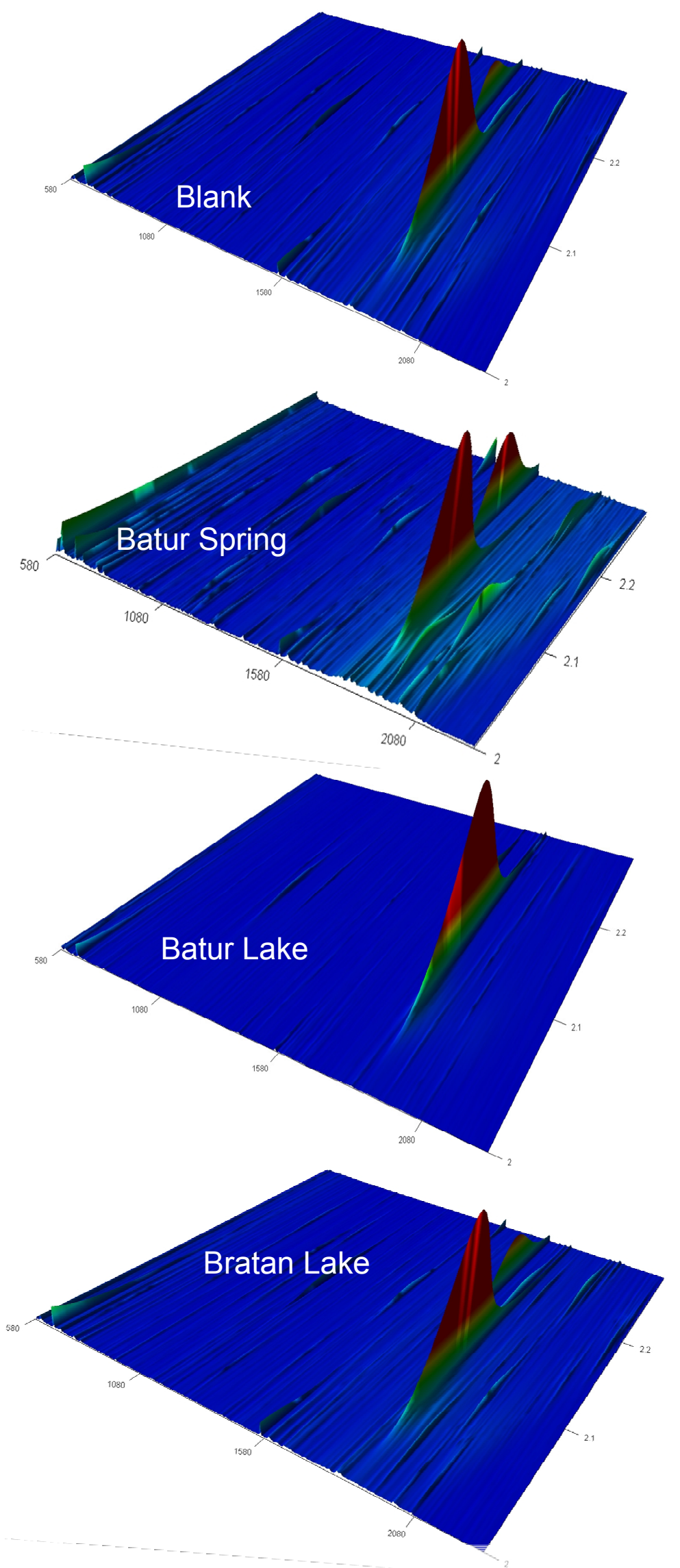

Figure 7. 3D chromatograms of blank and DCM extracts of Batur Spring, Batur, and Bratan Lake water in the retention time range for the second column from 2000 to 2300. 
The differences in the fatty acid content and concentrations in both lakes may have resulted from a difference in the cyanobacteria species composition, a different content of dissolved $\mathrm{CO}_{2}$ and nitrogen in the water of both lakes (also in the inflowing Batur Spring water), and the significant difference in their water ionic and trace metal composition. The more alkaline Batur Lake water, also deficient in $\mathrm{CO}_{2}$, probably promotes the growth of cyanobacteria whose cell membranes include oleic and linonenic acids. At the same time, the poorly mineralized water of the Bratan Lake, with a neutral $\mathrm{pH}$ and similar $\mathrm{N}$ content, represents a different fatty acid profile, likely promoting the oleic and linonenic acids' biodegradation [18-21].

\section{Conclusions}

The results of our study on the abundance of major, minor, trace elements and organic compounds in the water from two different caldera lakes indicate that their chemistry is the result of important interactions among water, volcanic gases and the local substratum. In terms of pollution, the most important feature was the detection of multiple trace elements. The organic compounds were connected to local biota, and some of them could be used as distinguishing factors between the two lakes. The conducted research shows that water from both lakes significantly differs in cation $\left(\mathrm{Na}^{+}\right.$, $\left.\mathrm{K}^{+}, \mathrm{Mg}^{2+}, \mathrm{Ca}^{2+}\right)$ and anion $\left(\mathrm{SO}_{4}{ }^{2-}, \mathrm{F}^{-}, \mathrm{Cl}^{-}, \mathrm{Br}^{-}\right)$concentrations. The mentioned parameters are around 100 times higher in Batur Lake than Bratan Lake. Similar differences are also noted for conductivity and $\mathrm{pH}$. The concentration levels of the mentioned ions and conductivity of Batur Spring water were very similar to the Batur Lake water. Their almost identical ionic composition of water strengthens the statement that this spring provides the main inflow supply for Batur Lake; however, a common groundwater source could not be excluded.

The concentration levels of trace elements in Batur Lake are found to be several to several hundred times higher than in Bratan Lake. However, the concentration levels in the water of Batur Lake and Batur Spring were very similar. On the other hand, the concentration levels of ions present in Bratan Lake are comparable to concentrations determined in the precipitate observed in the area of interest, as it is the main factor of loading water into this lake [22-24].

The presence of organic compounds in lakes results mainly from biological activity of microorganisms inhabiting them such as bacteria, plankton and zooplankton. The conducted research facilitates a comparison of the composition and level of fatty acid occurrence (the indicators of cyanobacteria presence) and the obtained results suggest diversity of microorganisms inhabiting both lakes.

\section{Acknowledgments}

Publication of the paper has been financed from the funds of the Leading National Research Centre (KNOW) received by the Centre for Polar Studies, University of Silesia, Poland for the period 2014-2018. Authors would like to thank the Head of Department of Analytical Chemistry of Gdansk University of Technology, Jacek Namieśnik for the opportunity of access to powerful device (GCxGC-MS/TOF) which allow to use a highly advanced analytical technique of two-dimensional gas chromatography. Special thanks to Tomasz Dymerski, Marek Tobiszewski and Paulina Bigus for care of the chromatographic device during the analysis, valuable tips and support. 


\section{Author Contributions}

Żaneta Polkowska designed the concept, selection of the study area, designed the experiment, analyzed and interpreted the data and wrote the draft of the manuscript, reviewed the final manuscript. Lidia Wolska provided his support and guidance throughout the field experiment, analyzed and interpreted the data and wrote the draft of the manuscript, reviewed the final manuscript. Leszek Łęczyński interpreted the results and prepared the manuscript, prepared figures. Marek Ruman selection of the study area, supervised data collection, helped with gathering field data, prepared figures, elaboration of geographic data and maps, reviewed the final manuscript. Sara Lehmann chemical and physical properties analysis. Katarzyna Kozak chemical and physical properties analysis, reviewed the final manuscript. Magdalena Matysik helped with gathering field data, supervised data collection, elaboration of geographic data and maps. Damian Absalon helped with gathering field data, supervised data collection, elaboration of geographic data and maps

\section{Conflicts of Interest}

The authors declare no conflict of interest.

\section{References}

1. Varekamp, J.C.; Kreulen, R. The stable isotope geochemistry of volcanic lakes, with examples from Indonesia. J. Volcanol. Geotherm. Res. 2000, 97, 309-327.

2. Cole, J.W.; Milne, D.M. Calderas and caldera structures: A review. Earth-Sci. Rev. 2005, 69, 1-26.

3. Varekamp, J.C.; Pasternack, G.B.; Rowe, G.L., Jr. Volcanic lake systematics II: Chemical constraints. J. Volcanol. Geotherm. Res. 2000, 97, 161-179.

4. Reubi, O.; Nicholls, I.A. Structure and Dynamics of a Silicic Magmatic System Associated with Caldera-Forming Eruptions at Batur Volcanic Field, Bali, Indonesia. J. Petrol. 2005, 46, 1367-1391.

5. Sutawidjaja, I.S. Ingnimbrite analyses of Batur Caldera Bali, based on ${ }^{14} \mathrm{C}$ dating. J. Geol. Indones. 2008, 4, 189-202.

6. Watanabe, K.; Yamanaka, T.; Harijoko, A.; Saitra, C.; Warmada, I.W. Caldera activities in North Bali Indonesia. J. Southeast Asian Appl. Geol. 2010, 2, 283-290.

7. Lehmusluoto, P.; Machbub, B.; Terangna, N.; Rusmiputro, S.; Achmad, F.; Boer, L.; Brahmana, S.S.; Priadi, B.; Setiadji, B.; Sayuman, O.; et al. National Inventory of the Major Lakes and Reservoirs in Indonesia-General Limnology; Expedition Indodanau Technical Report; University of Helsinki: Helsinki, Finland, 1997.

8. Tsuzuki, M.; Ohnuma, E.; Sato, N.; Takaku, T.; Kawaguchi, A. Effects of $\mathrm{CO}_{2}$ Concentration during Growth on Fatty Acid Composition in Microalgae. Plant Physiol. 1990, 93, 851-856.

9. Delmelle, P.; Bernard, A. Downstream composition changes of acidic volcanic waters discharged into the Banyupahit stream, Ijen caldera, Indonesia. J. Volcanol. Geotherm. Res. 2000, 97, 55-75.

10. Reubi, O.; Nicholls, I.A. Magmatic evolution at Batur volcanic field, Bali, Indonesia: Petrological evidence for polybaric fractional crystallization and implications for caldera-forming eruptions. J. Volcanol. Geotherm. Res. 2004, 138, 345-369.

11. Moune, S.; Gauthier, P.J.; Delmelle, P. Trace elements in the particulate phase of the plume of Masaya Volcano, Nicaragua. J. Volcanol. Geotherm. Res. 2010, 193, 232-244. 
12. Delmelle, P. Environmental impacts of tropospheric volcanic gas plumes. Volcan. Degassing 2003, 213, 381-399.

13. Kim, J. Fate of THMs and HAAs in low TOC surface water. Environ. Res. 2009, 109, 158-165.

14. Parszuto, K.; Teodorowicz, M.; Grochowska, J. Relationship between organic carbon and other measures of organic matter in the waters of Lake Isąg. Limnol. Rev. 2006, 6, 233-238.

15. Greenwood, P.F.; Brocks, J.J.; Grice, K.; Schwark, L.; Jaraula, C.M.B.; Dick, J.M.; Evans, K.A. Organic geochemistry and mineralogy. I: Characterization of organic matter associated with metal deposits. Ore Geol. Rev. 2013, 50, 1-27.

16. Baecelona, M.J. TOC determinations in ground water. Ground Water 1984, 22, 18-24.

17. Henriksen, A.; Brakke, D.F.; Nortonc, S.A. Total organic carbon concentrations in acidic lakes in Southern Norway. Environ. Sci. Technol. 1988, 22, 1103-1105.

18. Ǩezanka, T.; Dor, I.; Prell, A.; Dembitsky, V.M. Fatty acid composition of six freshwater wild cyanobacterial species. Folia Microbiol. 2003, 48, 71-75.

19. Kaneshiro, T.; Nakamura, L.K.; Bagby, M.O. Oleic acid transformations by selected strains of Sphingobacterium thalpophilum and Bacillus cereus from composted manure. Curr. Microbiol. 1995, 31, 62-67.

20. Sushanta, K.S.; Lakshmanan, U.; Gopalakrishnan, S. Nitrogen stress induced changes in the marine cyanobacterium Oscillatoria willei BDU 130511, FEMS. Microbiol. Ecol. 2003, 45, 263-272.

21. Liu, J.; Shi, L. Analysis of chemical composition of precipitation in a typical background site. J. Environ. Sci. 1998, 10, 325-333.

22. Bruijnzeel, L.A. Nutrient content of bulk precipitation in south-central Java, Indonesia. J. Trop. Ecol. 1989, 5, 187-202.

23. Sanford, W.E.; Konikow, L.F.; Rowe, G.; Brantley, S.L. Ground-water transport of crater-lake brine at Poas Volcano, Costa Rica. J. Volcanol. Geotherm. Res. 1995, 64, 271-297.

24. Wheller, G.E.; Varne, R. Genesis of dacitic magmatism at Batur volcano, Bali, Indonesia: Implications for the origins of stratovolcano calderas. J. Volcanol. Geotherm Res. 1986, 28, 363-378.

(C) 2015 by the authors; licensee MDPI, Basel, Switzerland. This article is an open access article distributed under the terms and conditions of the Creative Commons Attribution license (http://creativecommons.org/licenses/by/4.0/). 